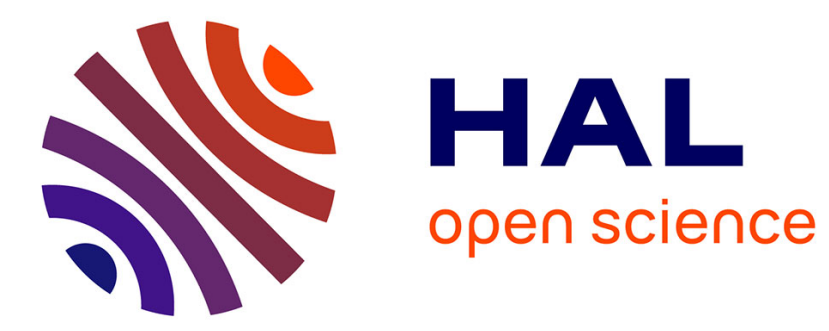

\title{
Tubulin polyglutamylation, a regulator of microtubule functions, can cause neurodegeneration
}

\author{
Satish Bodakuntla, Carsten Janke, Maria M Magiera
}

\section{To cite this version:}

Satish Bodakuntla, Carsten Janke, Maria M Magiera. Tubulin polyglutamylation, a regulator of microtubule functions, can cause neurodegeneration. Neuroscience Letters, 2021, 746, pp.135656. 10.1016/j.neulet.2021.135656 . hal-03323738

\section{HAL Id: hal-03323738 \\ https://hal.science/hal-03323738}

Submitted on 23 Aug 2021

HAL is a multi-disciplinary open access archive for the deposit and dissemination of scientific research documents, whether they are published or not. The documents may come from teaching and research institutions in France or abroad, or from public or private research centers.
L'archive ouverte pluridisciplinaire HAL, est destinée au dépôt et à la diffusion de documents scientifiques de niveau recherche, publiés ou non, émanant des établissements d'enseignement et de recherche français ou étrangers, des laboratoires publics ou privés. 
Tubulin polyglutamylation, a regulator of microtubule functions, can cause neurodegeneration

Satish Bodakuntla, Carsten Janke* and Maria M. Magiera*

${ }^{1}$ Institut Curie, PSL Research University, CNRS UMR3348, F-91401 Orsay, France

${ }^{2}$ Université Paris Sud, Université Paris-Saclay, CNRS UMR3348, F-91401 Orsay, France

*corresponding authors:

Maria M. Magiera, Carsten Janke, Institut Curie, rue Henri Becquerel, Centre Universitaire, Bâtiment 110, F-91401 Orsay, France

Telephone: +33 1 69863088; +33 1 69863127; Email: Maria.Magiera@curie.fr;

Carsten.Janke@curie.fr 


\begin{abstract}
Neurodegenerative diseases lead to a progressive demise of neuronal functions that ultimately results in neuronal death. Besides a large variety of molecular pathways that have been linked to the degeneration of neurons, dysfunctions of the microtubule cytoskeleton are common features of many human neurodegenerative disorders. Yet, it is unclear whether microtubule dysfunctions are causative, or mere bystanders in the disease progression. A so-far little explored regulatory mechanism of the microtubule cytoskeleton, the posttranslational modifications of tubulin, emerge as candidate mechanisms involved in neuronal dysfunction, and thus, degeneration. Here we review the role of tubulin polyglutamylation, a prominent modification of neuronal microtubules. We discuss the current understanding of how polyglutamylation controls microtubule functions in healthy neurons, and how deregulation of this modification leads to neurodegeneration in mice and humans.
\end{abstract}




\section{Introduction}

Microtubules are key structural components of the neuronal cytoskeleton. They are involved in the establishment and maintenance of neuronal polarity, axon growth and branching, and serve as tracks for trafficking of cargoes in neurons [23, 52, 54]. A growing body of evidence points toward dysfunctions of the microtubule cytoskeleton in the pathogenesis of several neurodegenerative diseases $[21,79,98]$. Numerous genes mutated in the most common agerelated neurodegenerative disorders (Parkinson's, Huntington's and Alzheimer's diseases) are related either to microtubule stability (tau protein [37]), microtubule severing (spastin [101]), or microtubule-based transport (huntingtin, kinesin, dynein [79]). However, the role of microtubules themselves in the pathogenesis of neurodegenerative disorders has only recently begun to emerge.

Microtubules are subject to a wide range of posttranslational modifications [72]. The tubulin code concept (Fig. 1A) [47, 97] proposes that these modifications can functionally specialise individual microtubules, thus locally and temporally adapting them to their wide variety of functions within living cells. Perturbations of tubulin modifications are expected to cause microtubule dysfunctions, which in neurons could eventually lead to neurodegeneration. Here we review recent findings that demonstrate the role of polyglutamylation, a key modification of neuronal microtubules, in neurodegeneration. We critically evaluate how cellular and molecular mechanisms that are implicated in neurodegeneration could be induced by perturbed polyglutamylation.

\section{What is tubulin polyglutamylation?}

Polyglutamylation is a posttranslational modification that adds secondary peptide chains of glutamates to its target proteins (Fig. 1A). Polyglutamylation has been first identified on brain tubulin $[1,25,99]$, where it is highly enriched compared to most other tissues [128]. The first enzyme catalysing this novel modification was purified as a multi-protein complex from 
mouse brains $[48,93]$. Among the proteins of this complex was tubulin tyrosine ligase-like 1 (TTLL1), the catalytic subunit. This discovery bolstered the identification of additional TTLL enzymes, most of them catalysing polyglutamylation [45, 48, 124]. Strikingly, each TTLL enzyme generates a characteristic polyglutamylation pattern on tubulin (Fig. 1B) [124]. This specificity is determined by structural features within the active sites of those enzymes [73, 84]. Some glutamylases, such as TTLL4 and TTLL5, also modify other, non-tubulin substrates $[92,113,123]$. However, given that the main neuronal glutamylases TTLL1 [48] and TTLL7 [45] are tubulin-specific [71, 124], the glutamylation of non-tubulin substrates might play only minor roles in differentiated neurons.

Polyglutamylation is a reversible modification [2]. Enzymes responsible for deglutamylation belong to the family of cytosolic carboxypeptidases (CCP) [56, 96, 117]. Similar to glutamylases, deglutamylases have distinct enzymatic activities [6, 96, 129], thus allowing them to control the generation of specific polyglutamylation patterns on microtubules (Fig. 1B). CCPs also remove glutamates exposed on the carboxy-terminus of several proteins $[108,115]$ including detyrosinated $\alpha$-tubulin, thus generating another posttranslational modification of tubulin, $\Delta 2$-tubulin $[89,96]$.

\section{Perturbation of tubulin polyglutamylation causes neurodegeneration in mouse models}

The first mouse model of neurodegeneration to be linked to polyglutamylation was the Purkinje-cell degeneration $(p c d)$ mouse. This mouse was identified in the 1970ies, and since then studied as a model of neurodegeneration with a characteristic spontaneous degeneration of Purkinje cells in the cerebellum at about 1 month of age [82]. Apart from the degeneration of Purkinje cells, $p c d$ mice also display retina degeneration $[10,63]$, degeneration of the mitral cells in the olfactory bulb [38], degeneration of thalamic neurons $[85,86]$ and male sterility [41]. Early electron microscopy studies showed abnormal inclusions and organelle accumulation within the dendrites of degenerating Purkinje cells [61], which were postulated 
to play a role in the degenerative process. Later reports found defects in myelination [16], excessive DNA damage $[4,5,121]$, increased apoptosis $[33,34]$, endoplasmic reticulum (ER) stress [58], autophagy [7] and defects in synaptic connectivity [11, 61]. Excessive DNA damage and apoptosis were both excluded as potential causes of neurodegeneration in $p c d$ mice, as neither the inactivation of DNA repair, nor the disruption of apoptotic pathways prevented Purkinje cell degeneration [126].

The mutation causing the phenotypes of $p c d$ mice was later mapped to the Nnal gene, coding for a protein containing a zinc carboxypeptidase domain [29]. Rescue experiments showed that only an enzymatically active Nnal could prevent neurodegeneration in $p c d$ mice, thus demonstrating that the carboxypeptidase activity of this protein is essential for its neuroprotective function. However, the substrates modified by Nna1 were not known at the time [127]. The discovery that Nna1 is a member of a larger family of cytosolic carboxypeptidases (CCPs) [51, 95], which are involved in tubulin deglutamylation [8, 56, 96, 117] (Fig. 1B) strongly suggested that perturbed tubulin polyglutamylation could be the cause of the observed neurodegeneration in $p c d$ mice.

As predicted, $p c d$ mice showed excessive accumulation of tubulin polyglutamylation in the cerebellum and the olfactory bulb [96], two brain regions in which massive neurodegeneration had been described $[38,82]$. Assuming that excessive polyglutamylation is the primary cause of the observed degeneration implied that reducing polyglutamylation of tubulin, i.e. microtubules, in the affected neurons might prevent, or at least delay their degeneration. This could indeed be demonstrated by targeting the main neuronal polyglutamylase, TTLL1 [48]. Initial experiments using electroporation of interfering RNAs into cerebella of $p c d$ mice avoided the degeneration of some Purkinje cells [96]. In a more thorough genetic experiment, Ttll1 was knocked out selectively in Purkinje cells of pcd/Ttll1flox mice using Purkinje-cell specific expression of cre recombinase (L7-cre [94]). In these 
mice Purkinje cells did not degenerate, and even survived throughout the entire life of these mice [71]. This demonstrated that (i) accumulation of polyglutamylation on microtubules, generated by the tubulin-specific glutamylase Ttll1 is the cause of the degeneration observed in $p c d$ mice, and that (ii) this process is cell-autonomous, as it could be rescued by lowering tubulin polyglutamylation levels only in the Purkinje cells of the $p c d$ mice. These conclusions are further bolstered by earlier experiments, in which cerebellar tissue from wild-type mice was grafted into cerebella of $p c d$ mice. Not only did the tissue grafts survive in the $p c d$ brains; wild-type Purkinje cells also replaced the degenerated neurons and formed functional synaptic connections with the host brain $[32,112]$.

But why was the degeneration in $p c d$ mice limited to only some regions of the brain? One possible explanation was that other deglutamylases from the CCP family prevent hyperglutamylation in brain regions that remain unaffected, such as the cerebral cortex and the hippocampus. Indeed, when Ccp6, a deglutamylase strongly expressed in brain except for the cerebellum and the olfactory bulb [96], was depleted in $p c d$ mice, a strong accumulation of hyperglutamylation in previously unaffected brain regions was observed. Consequently, cortical pyramidal neurons were found to degenerate in the $C \operatorname{cp} 1 / C \operatorname{cp} 6$ double-knockout mice [71].

These mouse models established that increased tubulin polyglutamylation affects the survival of a large spectrum of neurons in the nervous system. It also revealed that different types of neurons are not equally sensitive to hyperglutamylation. In the cerebellum, for instance, Purkinje neurons die relatively synchronously within four weeks [82], while granule cells degenerate only partially and over a much longer time interval [118]. Mitral cells in the olfactory bulb, while morphologically similar to Purkinje cells, start to degenerate only after two months [38]. Finally, pyramidal neurons in the cerebral cortex are only reduced by about $20 \%$ after five months despite massive accumulation of hyperglutamylation in brains of 
$p c d / C c p 6($ Ccp 1/Ccp6) double knockout mice [71]. The reasons for the different time courses of degeneration of different neuronal populations could either be related to differences in their overall susceptibility to physiological perturbations $[31,102]$, or to different levels and activities of polyglutamylating enzymes [65]. Moreover, given that CCP1 has other, nontubulin substrates $[108,115]$, it cannot be excluded that deglutamylation of these proteins contributes to the degeneration of neurons in $p c d$ mice.

\section{The role of microtubule polyglutamylation in neuronal function}

The discovery that accumulation of polyglutamylation on microtubules is sufficient to induce neurodegeneration univocally demonstrated the importance of this tubulin modification for neuronal function and homeostasis. Determining which microtubule functions are controlled by polyglutamylation is therefore of key importance to understand the molecular mechanisms of this novel type of neurodegeneration.

\section{Microtubules and their many partners}

Polyglutamylation takes place at the carboxy-terminal tails of tubulins that decorate the outer surface of microtubules (Fig. 1A), and is thus expected to control interactions of microtubuleassociated proteins (MAPs) with microtubules (Fig. 2A). MAPs are a large, heterogenous family of proteins that interact with microtubules to control their dynamics, structure and function. The so-called 'structural MAPs' are thought to stabilise microtubules [12]. In neurons, predominant MAPs of this group are tau, a key player in Alzheimer's disease [36], as well as MAP1A, MAP1B and MAP2. Another group of microtubule-interacting proteins are the microtubule-severing enzymes spastin, katanin and fidgetin, which regulate microtubule mass and dynamics in cells [77]. In neurons, these enzymes play important roles in axon outgrowth and plasticity $[18,28,100]$. Mutations in spastin are linked to the most frequent form of a neurodegenerative disorder, hereditary spastic paraplegia [27, 30, 42]. 
Microtubules are the 'tracks' for molecular motors such as kinesins and dynein. In neurons, these motor proteins play a pivotal role in transporting a wide range of cargoes to distinct subcellular locations, thus assuring neuronal function and survival [40,70]. Given the complex architecture of many neurons, it is not surprising that defects in neuronal transport are common features of human neurodegenerative diseases $[17,22,55,79,110,122]$. In fact, transport defects, and therefore microtubule dysfunctions, might act upstream of other pathogenic events in neurodegenerative diseases $[9,111]$.

\section{Polyglutamylation as regulator of microtubule interactors (Fig. 2A)}

A large variety of microtubule-interacting proteins play key roles in neurons, and many of them have also been linked to neurodegenerative disorders. Even more strikingly, most of these proteins have also been linked to microtubule polyglutamylation. Early studies have suggested that binding affinity of several major neuronal MAPs, such as tau, MAP1B and MAP2 to tubulin is regulated by polyglutamylation $[14,15]$. These results were obtained under non-native conditions and still await validation in native states. More thorough molecular insights have been gained on the regulation of the microtubule-severing enzyme spastin by polyglutamylation. Initial experiments in cells, and reconstitution of microtubule severing in cell-free conditions showed that in particular long polyglutamate chains on tubulin strongly induce severing by spastin [59]. More detailed analyses further revealed that polyglutamylation controls the severing activity of spastin in a non-linear, biphasic way: while the initial addition of the modification activated severing, further accumulation of polyglutamylation inhibited spastin activity [120]. In vivo observations suggested that katanin can also be activated by polyglutamylation of microtubules [106].

The molecular motors kinesin and dynein were long expected to be regulated by polyglutamylation. Early studies already suggested that kinesin motor proteins bind stronger to polyglutamylated tubulin [62]. First functional evidence obtained by direct measurements 
of motor protein movement on native microtubules showed that polyglutamylation can regulate the motility of several motor proteins. Strikingly, different patterns of polyglutamylation had distinct effects on velocity and processivity of the motors, and not all motor proteins were affected in the same way [64, 109].

\section{Polyglutamylation regulates cargo traffic in neurons (Fig. 2B)}

Motor proteins in differentiated neurons are heavily implicated in intracellular cargo transport, which needs to cover long distances $[19,70]$. It was therefore intuitive to hypothesise that polyglutamylation of microtubules could act as a regulator of neuronal traffic. Early indications for a role of polyglutamylation in intracellular transport came from observations in mice lacking the polyglutamylase subunit 1 (PGs1) of the TTLL1 complex, which show reduced polyglutamylation in the brain. In neurons of these mice, the kinesin motor KIF1A was unable to move into neurites, while two other kinesins, KIF3A and KIF5, were not affected. Given that the KIF1A motor is particularly involved in carrying synaptic cargoes [67], this study suggested that polyglutamylation could regulate the delivery of synaptic vesicles, and might therefore also affect synaptic transmission [44]. Indeed, first insight into how synaptic activity could control postsynaptic cargo transport by modulating polyglutamylation was provided by another study. Activating hippocampal neurons by either stimulating AMPA ( $\alpha$-amino-3-hydroxyl-5-methyl-4-isoxazole-propionate)-type glutamate receptors, or by inhibiting glycine-responsive receptors resulted in strongly increased levels of tubulin polyglutamylation, and a concomitant accumulation of vesicles containing the synapse-scaffolding protein gephyrin [119] in the cell bodies. Strikingly, the vesicle transport was restored when TTLL1 was downregulated, strongly suggesting that polyglutamylation directly controls the trafficking of these vesicles [69]. This was recently confirmed in a mouse model where lack of spastin leads to microtubule hyperglutamylation and reduced delivery of AMPA receptors to synapses [68]. 
In primary hippocampal neurons cultured from hyperglutamylation mouse models, mitochondria, lysosomes, LAMP1 endosomes and BDNF (brain-derived neurotrophic factor) vesicles consistently showed reduced motility, though mitochondria and BDNF vesicles appeared to be most affected $[13,71]$. Strikingly, the impact of polyglutamylation on the transport of these cargoes appeared to be cell-type specific: while in hippocampal neurons both, mitochondria and lysosomes were affected by hyperglutamylation [13], mitochondria, but not lysosomes showed reduced transport in cerebellar granule neurons [35]. The reasons for these differences are not yet understood, but it is clear that cell-type specific microtubule properties, as well as the differential expression of enzymes involved in polyglutamylation could be involved [65].

By which mechanism does polyglutamylation induce neurodegeneration? (Fig. 2C)

To determine the molecular causes of hyperglutamylation-induced neurodegeneration, different mechanisms were tested. Given that increased polyglutamylation is known to induce microtubule severing $[59,120]$, the role of spastin was tested by generating a $p c d(C c p 1) /$ spastin double-knockout mouse. If the increased polyglutamylation in $p c d$ mice would have contributed to the early degeneration of Purkinje cells via the stimulation of spastin-mediated severing, then deletion of spastin should rescue this phenotype. This, however, was not the case [71]. Instead, the observation of organelle accumulation in axons of mice with hyperglutamylation-induced neurodegeneration pointed towards defects in axonal transport. Indeed, perturbed cargo traffic was identified in neurons from these mice $[13,35,71]$, but so far, no direct evidence for a causative role of transport defects could be provided.

Another important player in neurodegeneration are MAPs, in particular tau protein. Exposing cultured neurons to toxic beta-amyloid oligomers caused an upregulation of polyglutamylation on dendritic microtubules, which was accompanied by missorting of tau 
protein from its typical axonal into more dendritic localisations. This was accompanied by microtubule loss [130], a common end point in neurodegenerative diseases [49]. Polyglutamylation was suggested to directly cause these two phenotypes given its known role in regulating tau-tubulin interactions [15] and spastin-mediated microtubule severing [59, 120].

Whether the proposed mechanisms work alone or in synergy, and to which extent they differ between different neurodegenerative disorders still remains an open question. Many microtubule-based mechanisms are interconnected, and polyglutamylation might affect several of them. Some MAPs have been shown to directly influence microtubule-based traffic $[43,80,107,114]$, and MAPs themselves compete on the microtubule lattice, which might allow a coordinated traffic control in cells [81]. Loss of the microtubule-severing enzyme spastin has recently been demonstrated to increase microtubule polyglutamylation in neurons, which in turn led to a reduced efficiency of neuronal transport [68]. Finally, MAPs have been suggested to shield microtubules from severing enzymes [91], thus controlling microtubule dynamics in cells. To which extent polyglutamylation can control these processes needs to be determined.

Given that combinations of polyglutamylases and deglutamylases allow for the generation of many different modification patterns on cellular microtubules, it is possible that polyglutamylation plays the role of central controller that coordinates the behaviour of multiple microtubule interactors in a targeted manner. This would provide a paradigm by which this modification could control microtubule dynamics, stability, and microtubule-based transport in neurons. It also implies that perturbations of this process do not affect a single, but rather several interconnected microtubule-based processes, which could synergistically contribute to the degeneration of neurons. 


\section{Tubulin polyglutamylation and its links to human neurodegeneration}

The first human neurodegenerative disorder that has been directly linked to deregulated tubulin polyglutamylation was an infantile-onset, progressive neurodegeneration of the central and peripheral nervous systems caused by mutations in $C C P 1$. Most obvious pathological representations of this disease are cerebellar atrophy and lower motor neuron degeneration $[53,104,105]$. As in the $p c d$ mouse model, the CCP1 mutations found in these patients consistently led to enzymatically inactive variants of CCP1. Many of the pathological hallmarks described in those patients are recapitulated in the $p c d$ mice, which makes these mice an excellent model to study the human disease. It also allows the cautious conclusion that, similar to what has been shown in $p c d$ mice, the degeneration in CCP1 patients might be prevented by interfering with the polyglutamylating enzyme TTLL1 [71, 104]. Most importantly, the high similarity between the pathologies in mice and men also point to the possibility that new insights obtained from other mouse models with perturbed polyglutamylation are relevant in humans. For instance, mice lacking $C c p 1$ and $C c p 6$ have been used to demonstrate that perturbed polyglutamylation in the cerebral cortex leads to the degeneration of pyramidal neurons [71]. Pyramidal neurons are often affected in human lateonset neurodegenerative disorders, such as Alzheimer's disease [74], which opens the exciting perspective that perturbation of polyglutamylation could be involved in the pathology of these disorders.

Mechanisms that lead to deregulation of polyglutamylation in neurodegenerative diseases could be diverse. Mutations in other genes involved in polyglutamylation often lead to less obvious defects in mice, but might cause yet unexplored subtle defects in human neurons, especially given the longer life span of humans as compared to mice. It is also possible that polyglutamylation is deregulated by changing expression patterns of polyglutamylation- 
related enzymes, or their posttranslational regulation, fields that have so far been little explored.

Several examples for dysregulation of enzymes catalysing polyglutamylation have already been found in genome-wide analyses of patients with neurodegeneration. A clinical study of 2,237 individuals revealed a strong association of single nucleotide polymorphisms (SNPs) in the $A G B L 1$ gene, coding for the deglutamylase CCP4, with learning disorders [78]. Recent studies using single-nucleus RNA sequencing and transcriptomics on samples from Alzheimer's disease patients showed differential expression of TTLL7, one of the two major brain glutamylase, in oligodendrocytes [39, 76]. Whole-exome sequencing [125] and proteomic studies [103] identified $A G B L 3$ (encoding the deglutamylase CCP3) as one of the genes linked to early-onset Alzheimer's disease. The $A G B L 2$ gene, encoding the CCP2 deglutamylase, was shown to be present at a locus associated with susceptibility to Alzheimer's disease [60]. Both, CCP2 and CCP3 are deglutamylases expressed in the brain, but at relatively low levels. Knocking out both enzymes in mice did not lead to any obvious neurological phenotypes [117]. However, this does not exclude that these enzymes have specific functions in neurons that, when perturbed, could lead to late-onset defects followed by degeneration in humans. Given the rapid increase in the landscape of studies reporting mutations in polyglutamylation enzymes, it is conceivable that alterations of this modifications directly or in combination with additional risk factors could be linked to other late-onset human neurodegenerative diseases [57].

\section{Conclusion and perspective}

The microtubule cytoskeleton plays undisputedly an important role in many neurodegenerative diseases. However, which molecular processes are perturbed by microtubule dysfunction has remained an open question, in particular in late-onset, progressive neurodegenerative disorders such as Alzheimer's or Parkinson's diseases. The 
recent discovery that the deregulation of a posttranslational modification of tubulin polyglutamylation - directly causes the degeneration of neurons opens a novel perspective in the research of causes of neurodegeneration. Modulations of the microtubules themselves have timidly emerged as possible causes of neuronal dysfunctions: A growing number of tubulin mutations lead to neurodevelopmental disorders, and occasionally are also linked to neurodegeneration $[20,116]$. Deregulation of other tubulin modifications, such as detyrosination and acetylation, were linked to neurodevelopmental processes $[26,50,66,75]$, synaptic function $[87,90]$, and disease $[24,46,88,131]$. This multitude of processes have in common that they potentially modulate microtubule properties and functions, thus impacting, in many cases subtly, the physiological functions of the microtubule cytoskeleton [47]. Polyglutamylation stands out as it has so far not been linked to neurodevelopment, but specifically to degeneration. This converges with the observation that polyglutamylation accumulates in differentiated neurons $[2,3]$, and most enzymes catalysing polyglutamylation are prominently expressed in the adult brain [13]. Hence, polyglutamylation emerges as a promising mechanism and a potential druggable target in several neurodegenerative diseases. 


\section{Figures}
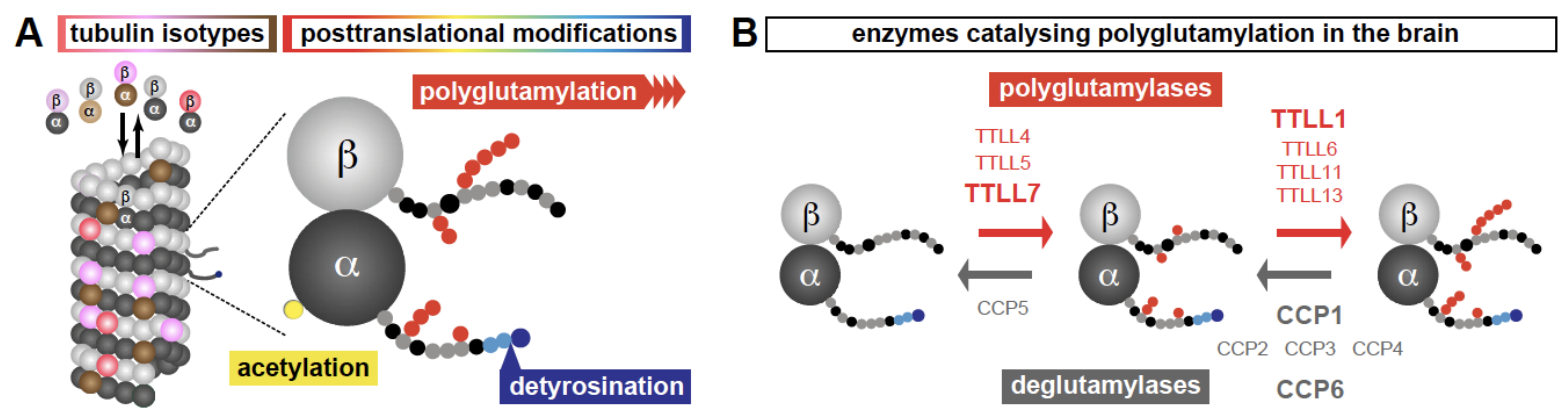

Figure 1: Tubulin polyglutamylation is part of the tubulin code that generates microtubule diversity

A) Mechanisms to generate molecular heterogeneity of microtubules: microtubules are dynamically assembled from different $\alpha$ - and $\beta$-tubulins. Tubulins are also subject to a variety of posttranslational modifications. In the nervous system, the key modifications are acetylation, polyglutamylation and detyrosination. B) Polyglutamylation is catalysed by a variety of enzymes from the tubulin-tyrosine-ligase-like (TTLL) family. These enzymes have distinct specificities that allow them to generate specific modification patterns, which in turn could regulate specific functions of the microtubule cytoskeleton (Fig. 2). Polyglutamylation is removed by enzymes of the cytosolic carboxypeptidase (CCP) family. The key enzymes expressed in neurons and brain $[45,48]$ are shown in bold. 

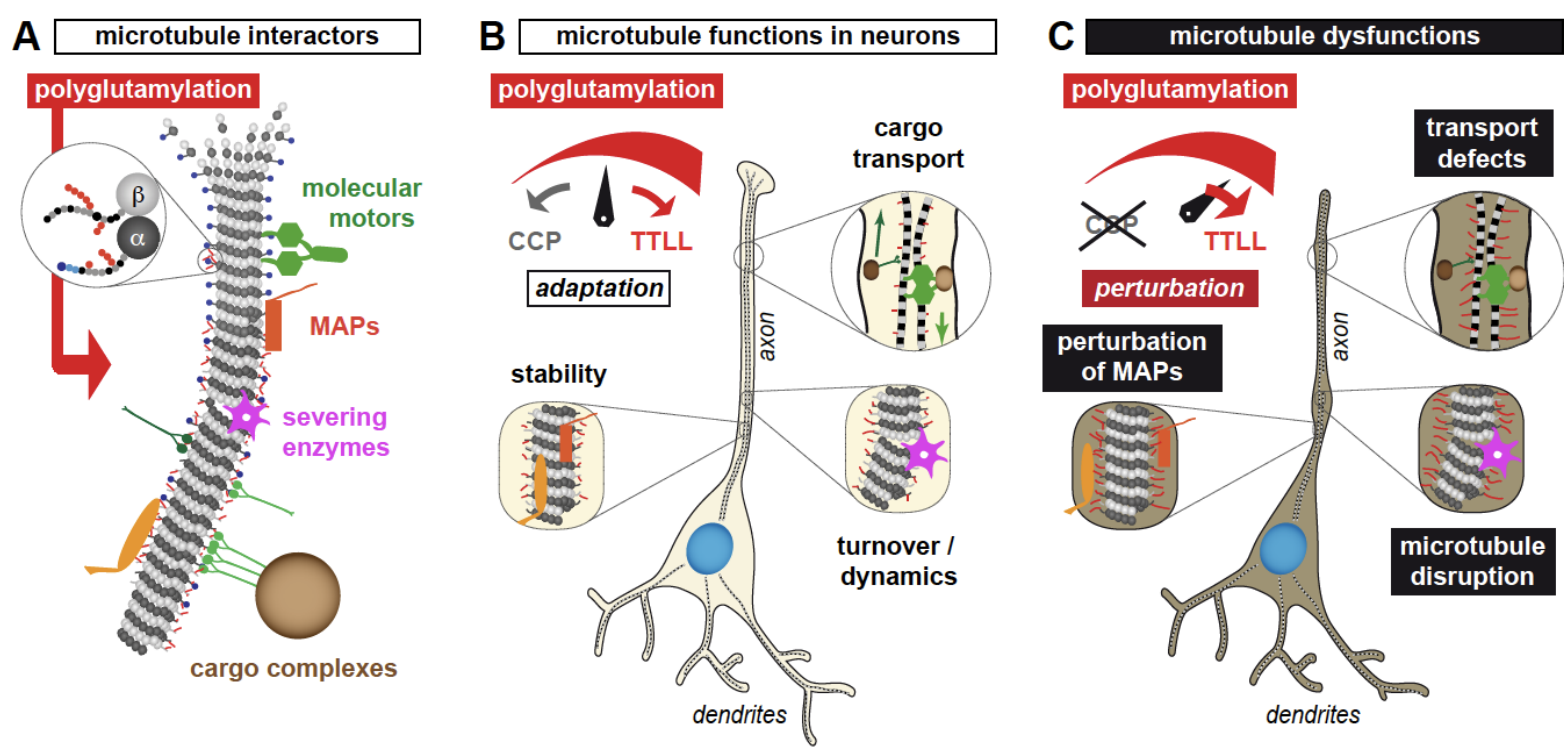

Figure 2: Regulation of the microtubule cytoskeleton by polyglutamylation, and perturbations potentially liked to neurodegeneration

Tubulin polyglutamylation (red tails on the microtubules) controls different functions of microtubules that are critical for the maintenance of cytoskeletal functions in neuron. A) On the molecular level, microtubule polyglutamylation regulates the binding and behaviour of microtubule-associated proteins (MAPs), the activity of microtubule-severing enzymes and the motility of some molecular motors and transport complexes. B) In healthy neurons, polyglutamylases (TTLLs) and deglutamylases (CCPs) control the levels of tubulin polyglutamylation on axonal and dendritic microtubules. The interplay between these enzymes acts like a rheostat to adapt microtubule properties and functions to specific physiological requirements. C) Deregulation or mutation of enzymes involved in polyglutamylation (shown here: loss of CCP deglutamylases, leading to hyperglutamylation and neurodegeneration $[71,96,104])$ perturbs this balance, which ultimately leads to microtubule dysfunctions in axons and dendrites. So far, defects in cargo transport have been demonstrated $[13,35,71]$, however, perturbed binding of MAPs, and altered microtubule dynamics have also been detected and might contribute to the degeneration $[68,83,130]$. 


\section{Acknowledgements}

This work was supported by the ANR-10-IDEX-0001-02, the LabEx CelTisPhyBio ANR-11LBX-0038. CJ is supported by the Institut Curie, the French National Research Agency (ANR) award ANR-17-CE13-0021, and the Fondation pour la Recherche Medicale (FRM) grant DEQ20170336756. MMM is supported by the France Alzheimer grant 2023, ASL-HSP France Foundation grant 2019 and the Tom Wahlig Foundation grant 2019, and SB by the FRM grant FDT201805005465.

\section{Author contributions}

All authors researched data for the article, contributed to discussion of the content, wrote the article, reviewed and edited the manuscript.

\section{Competing interests}

The authors declare no competing interests. 


\section{References}

[1] J.E. Alexander, D.F. Hunt, M.K. Lee, J. Shabanowitz, H. Michel, S.C. Berlin, T.L. MacDonald, R.J. Sundberg, L.I. Rebhun, A. Frankfurter, Characterization of posttranslational modifications in neuron-specific class III beta-tubulin by mass spectrometry, Proc Natl Acad Sci U S A 88 (1991) 4685-4689.

[2] S. Audebert, E. Desbruyeres, C. Gruszczynski, A. Koulakoff, F. Gros, P. Denoulet, B. Eddé, Reversible polyglutamylation of alpha- and beta-tubulin and microtubule dynamics in mouse brain neurons, Mol Biol Cell 4 (1993) 615-626.

[3] S. Audebert, A. Koulakoff, Y. Berwald-Netter, F. Gros, P. Denoulet, B. Eddé, Developmental regulation of polyglutamylated alpha- and beta-tubulin in mouse brain neurons, J Cell Sci 107 (1994) 2313-2322.

[4] F.C. Baltanas, I. Casafont, V. Lafarga, E. Weruaga, J.R. Alonso, M.T. Berciano, M. Lafarga, Purkinje cell degeneration in pcd mice reveals large scale chromatin reorganization and gene silencing linked to defective DNA repair, J Biol Chem 286 (2011) 28287-28302.

[5] F.C. Baltanas, I. Casafont, E. Weruaga, J.R. Alonso, M.T. Berciano, M. Lafarga, Nucleolar disruption and cajal body disassembly are nuclear hallmarks of DNA damage-induced neurodegeneration in purkinje cells, Brain Pathol 21 (2011) 374-388.

[6] I. Berezniuk, P.J. Lyons, J.J. Sironi, H. Xiao, M. Setou, R.H. Angeletti, K. Ikegami, L.D. Fricker, Cytosolic carboxypeptidase 5 removes alpha- and gamma-linked glutamates from tubulin, J Biol Chem 288 (2013) 30445-30453.

[7] I. Berezniuk, J. Sironi, M.B. Callaway, L.M. Castro, I.Y. Hirata, E.S. Ferro, L.D. Fricker, CCP1/Nna1 functions in protein turnover in mouse brain: Implications for cell death in Purkinje cell degeneration mice, Faseb J 24 (2010) 1813-1823.

[8] I. Berezniuk, H.T. Vu, P.J. Lyons, J.J. Sironi, H. Xiao, B. Burd, M. Setou, R.H. Angeletti, K. Ikegami, L.D. Fricker, Cytosolic Carboxypeptidase 1 Is Involved in Processing alpha- and beta-Tubulin, J Biol Chem 287 (2012) 6503-6517.

[9] L.G. Bilsland, E. Sahai, G. Kelly, M. Golding, L. Greensmith, G. Schiavo, Deficits in axonal transport precede ALS symptoms in vivo, Proc Natl Acad Sci U S A 107 (2010) 20523-20528.

[10] J.C. Blanks, R.J. Mullen, M.M. LaVail, Retinal degeneration in the pcd cerebellar mutant mouse. II. Electron microscopic analysis, J Comp Neurol 212 (1982) 231-246.

[11] M. Blosa, C. Bursch, S. Weigel, M. Holzer, C. Jäger, C. Janke, R.T. Matthews, T. Arendt, M. Morawski, Reorganization of Synaptic Connections and Perineuronal Nets in the Deep Cerebellar Nuclei of Purkinje Cell Degeneration Mutant Mice, Neural Plast 2016 (2016) 2828536.

[12] S. Bodakuntla, A.S. Jijumon, C. Villablanca, C. Gonzalez-Billault, C. Janke, Microtubule-Associated Proteins: Structuring the Cytoskeleton, Trends Cell Biol 29 (2019) 804-819.

[13] S. Bodakuntla, A. Schnitzler, C. Villablanca, C. Gonzalez-Billault, I. Bieche, C. Janke, M.M. Magiera, Tubulin polyglutamylation is a general traffic-control mechanism in hippocampal neurons, J Cell Sci 133 (2020) 10.1242/jcs.241802.

[14] C. Bonnet, D. Boucher, S. Lazereg, B. Pedrotti, K. Islam, P. Denoulet, J.C. Larcher, Differential binding regulation of microtubule-associated proteins MAP1A, MAP1B, and MAP2 by tubulin polyglutamylation, J Biol Chem 276 (2001) 12839-12848. 
[15] D. Boucher, J.C. Larcher, F. Gros, P. Denoulet, Polyglutamylation of tubulin as a progressive regulator of in vitro interactions between the microtubule-associated protein Tau and tubulin, Biochemistry 33 (1994) 12471-12477.

[16] L. Bouslama-Oueghlani, R. Wehrle, C. Sotelo, I. Dusart, The developmental loss of the ability of Purkinje cells to regenerate their axons occurs in the absence of myelin: an in vitro model to prevent myelination, J Neurosci 23 (2003) 8318-8329.

[17] S.T. Brady, G.A. Morfini, Regulation of motor proteins, axonal transport deficits and adult-onset neurodegenerative diseases, Neurobiol Dis 105 (2017) 273-282.

[18] M.S. Brill, T. Kleele, L. Ruschkies, M. Wang, N.A. Marahori, M.S. Reuter, T.J. Hausrat, E. Weigand, M. Fisher, A. Ahles, S. Engelhardt, D.L. Bishop, M. Kneussel, T. Misgeld, Branch-Specific Microtubule Destabilization Mediates Axon Branch Loss during Neuromuscular Synapse Elimination, Neuron 92 (2016) 845-856.

[19] M. Burute, L.C. Kapitein, Cellular Logistics: Unraveling the Interplay Between Microtubule Organization and Intracellular Transport, Annu Rev Cell Dev Biol 35 (2019) 29-54.

[20] S. Chakraborti, K. Natarajan, J. Curiel, C. Janke, J. Liu, The emerging role of the tubulin code: From the tubulin molecule to neuronal function and disease, Cytoskeleton (Hoboken) 73 (2016) 521-550.

[21] K.J. De Vos, A.J. Grierson, S. Ackerley, C.C.J. Miller, Role of axonal transport in neurodegenerative diseases, Annu Rev Neurosci 31 (2008) 151-173.

[22] K.J. De Vos, M. Hafezparast, Neurobiology of axonal transport defects in motor neuron diseases: Opportunities for translational research?, Neurobiol Dis 105 (2017) 283-299.

[23] E.W. Dent, J.L. Callaway, G. Szebenyi, P.W. Baas, K. Kalil, Reorganization and movement of microtubules in axonal growth cones and developing interstitial branches, J Neurosci 19 (1999) 8894-8908.

[24] J.P. Dompierre, J.D. Godin, B.C. Charrin, F.P. Cordelieres, S.J. King, S. Humbert, F. Saudou, Histone deacetylase 6 inhibition compensates for the transport deficit in Huntington's disease by increasing tubulin acetylation, J Neurosci 27 (2007) 3571-3583.

[25] B. Eddé, J. Rossier, J.P. Le Caer, E. Desbruyeres, F. Gros, P. Denoulet, Posttranslational glutamylation of alpha-tubulin, Science 247 (1990) 83-85.

[26] C. Erck, L. Peris, A. Andrieux, C. Meissirel, A.D. Gruber, M. Vernet, A. Schweitzer, Y. Saoudi, H. Pointu, C. Bosc, P.A. Salin, D. Job, J. Wehland, A vital role of tubulintyrosine-ligase for neuronal organization, Proc Natl Acad Sci U S A 102 (2005) 78537858.

[27] A. Errico, A. Ballabio, E.I. Rugarli, Spastin, the protein mutated in autosomal dominant hereditary spastic paraplegia, is involved in microtubule dynamics, Hum Mol Genet 11 (2002) 153-163.

[28] C. Fassier, A. Freal, L. Gasmi, C. Delphin, D. Ten Martin, S. De Gois, M. Tambalo, C. Bosc, P. Mailly, C. Revenu, L. Peris, S. Bolte, S. Schneider-Maunoury, C. Houart, F. Nothias, J.-C. Larcher, A. Andrieux, J. Hazan, Motor axon navigation relies on Fidgetin-like 1-driven microtubule plus end dynamics, J Cell Biol 217 (2018) 17191738 .

[29] A. Fernandez-Gonzalez, A.R. La Spada, J. Treadaway, J.C. Higdon, B.S. Harris, R.L. Sidman, J.I. Morgan, J. Zuo, Purkinje cell degeneration (pcd) phenotypes caused by mutations in the axotomy-induced gene, Nna1, Science 295 (2002) 1904-1906.

[30] N. Fonknechten, D. Mavel, P. Byrne, C.S. Davoine, C. Cruaud, D. Boentsch, D. Samson, P. Coutinho, M. Hutchinson, P. McMonagle, J.M. Burgunder, A. Tartaglione, O. Heinzlef, I. Feki, T. Deufel, N. Parfrey, A. Brice, B. Fontaine, J.F. Prud'homme, J. 
Weissenbach, A. Durr, J. Hazan, Spectrum of SPG4 mutations in autosomal dominant spastic paraplegia, Human Molecular Genetics 9 (2000) 637-644.

[31] H. Fu, J. Hardy, K.E. Duff, Selective vulnerability in neurodegenerative diseases, Nat Neurosci 21 (2018) 1350-1358.

[32] R. Gardette, R.M. Alvarado-Mallart, F. Crepel, C. Sotelo, Electrophysiological demonstration of a synaptic integration of transplanted Purkinje cells into the cerebellum of the adult Purkinje cell degeneration mutant mouse, Neuroscience 24 (1988) 777-789.

[33] F. Gillardon, J. Baurle, U. Grusser-Cornehls, M. Zimmermann, DNA fragmentation and activation of c-Jun in the cerebellum of mutant mice (weaver, Purkinje cell degeneration), Neuroreport 6 (1995) 1766-1768.

[34] F. Gillardon, J. Bäurle, H. Wickert, U. Grüsser-Cornehls, M. Zimmermann, Differential regulation of bcl-2, bax, c-fos, junB, and krox-24 expression in the cerebellum of Purkinje cell degeneration mutant mice, J Neurosci Res 41 (1995) 708-715.

[35] S. Gilmore-Hall, J. Kuo, J.M. Ward, R. Zahra, R.S. Morrison, G. Perkins, A.R. La Spada, CCP1 promotes mitochondrial fusion and motility to prevent Purkinje cell neuron loss in ped mice, J Cell Biol 218 (2019) 206-219.

[36] M. Goedert, Alzheimer's and Parkinson's diseases: The prion concept in relation to assembled Abeta, tau, and alpha-synuclein, Science 349 (2015) 1255555.

[37] M. Goedert, D.S. Eisenberg, R.A. Crowther, Propagation of Tau Aggregates and Neurodegeneration, Annu Rev Neurosci 40 (2017) 189-210.

[38] C.A. Greer, G.M. Shepherd, Mitral cell degeneration and sensory function in the neurological mutant mouse Purkinje cell degeneration (PCD), Brain Res 235 (1982) 156-161.

[39] A. Grubman, G. Chew, J.F. Ouyang, G. Sun, X.Y. Choo, C. McLean, R.K. Simmons, S. Buckberry, D.B. Vargas-Landin, D. Poppe, J. Pflueger, R. Lister, O.J.L. Rackham, E. Petretto, J.M. Polo, A single-cell atlas of entorhinal cortex from individuals with Alzheimer's disease reveals cell-type-specific gene expression regulation, Nat Neurosci 22 (2019) 2087-2097.

[40] P. Guedes-Dias, E.L.F. Holzbaur, Axonal transport: Driving synaptic function, Science 366 (2019) science.aaw9997.

[41] M.A. Handel, M. Dawson, Effects on spermiogenesis in the mouse of a male sterile neurological mutation, purkinje cell degeneration, Gamete Research 4 (1981) 185-192.

[42] J. Hazan, N. Fonknechten, D. Mavel, C. Paternotte, D. Samson, F. Artiguenave, C.S. Davoine, C. Cruaud, A. Durr, P. Wincker, P. Brottier, L. Cattolico, V. Barbe, J.M. Burgunder, J.F. Prud'homme, A. Brice, B. Fontaine, B. Heilig, J. Weissenbach, Spastin, a new AAA protein, is altered in the most frequent form of autosomal dominant spastic paraplegia, Nat Genet 23 (1999) 296-303.

[43] P.J. Hooikaas, M. Martin, T. Muhlethaler, G.-J. Kuijntjes, C.A.E. Peeters, E.A. Katrukha, L. Ferrari, R. Stucchi, D.G.F. Verhagen, W.E. van Riel, I. Grigoriev, A.F.M. Altelaar, C.C. Hoogenraad, S.G.D. Rudiger, M.O. Steinmetz, L.C. Kapitein, A. Akhmanova, MAP7 family proteins regulate kinesin-1 recruitment and activation, J Cell Biol 218 (2019) 1298-1318.

[44] K. Ikegami, R.L. Heier, M. Taruishi, H. Takagi, M. Mukai, S. Shimma, S. Taira, K. Hatanaka, N. Morone, I. Yao, P.K. Campbell, S. Yuasa, C. Janke, G.R. Macgregor, M. Setou, Loss of alpha-tubulin polyglutamylation in ROSA22 mice is associated with abnormal targeting of KIF1A and modulated synaptic function, Proc Natl Acad Sci U S A 104 (2007) 3213-3218. 
[45] K. Ikegami, M. Mukai, J.-i. Tsuchida, R.L. Heier, G.R. Macgregor, M. Setou, TTLL7 is a mammalian beta-tubulin polyglutamylase required for growth of MAP2-positive neurites, J Biol Chem 281 (2006) 30707-30716.

[46] Z. Iqbal, H. Tawamie, W. Ba, A. Reis, B.A. Halak, H. Sticht, S. Uebe, N.N. Kasri, S. Riazuddin, H. van Bokhoven, R. Abou Jamra, Loss of function of SVBP leads to autosomal recessive intellectual disability, microcephaly, ataxia, and hypotonia, Genet Med 21 (2019) 1790-1796.

[47] C. Janke, M.M. Magiera, The tubulin code and its role in controlling microtubule properties and functions, Nat Rev Mol Cell Biol 21 (2020) 307-326.

[48] C. Janke, K. Rogowski, D. Wloga, C. Regnard, A.V. Kajava, J.-M. Strub, N. Temurak, J. van Dijk, D. Boucher, A. van Dorsselaer, S. Suryavanshi, J. Gaertig, B. Eddé, Tubulin polyglutamylase enzymes are members of the TTL domain protein family, Science 308 (2005) 1758-1762.

[49] D.C. Jean, P.W. Baas, It cuts two ways: microtubule loss during Alzheimer disease, EMBO J 32 (2013) 2900-2902.

[50] B.V. Jenkins, H.A.J. Saunders, H.L. Record, D.M. Johnson-Schlitz, J. Wildonger, Effects of mutating alpha-tubulin lysine 40 on sensory dendrite development, J Cell Sci 130 (2017) 4120-4131.

[51] E. Kalinina, R. Biswas, I. Berezniuk, A. Hermoso, F.X. Aviles, L.D. Fricker, A novel subfamily of mouse cytosolic carboxypeptidases, Faseb J 21 (2007) 836-850.

[52] L.C. Kapitein, K.W. Yau, C.C. Hoogenraad, Microtubule dynamics in dendritic spines, Methods Cell Biol 97 (2010) 111-132.

[53] M. Karakaya, C. Paketci, J. Altmueller, H. Thiele, I. Hoelker, U. Yis, B. Wirth, Biallelic variant in AGTPBP1 causes infantile lower motor neuron degeneration and cerebellar atrophy, Am J Med Genet A 179 (2019) 1580-1584.

[54] M.T. Kelliher, H.A. Saunders, J. Wildonger, Microtubule control of functional architecture in neurons, Curr Opin Neurobiol 57 (2019) 39-45.

[55] H.J. Kim, J.P. Taylor, Lost in Transportation: Nucleocytoplasmic Transport Defects in ALS and Other Neurodegenerative Diseases, Neuron 96 (2017) 285-297.

[56] Y. Kimura, N. Kurabe, K. Ikegami, K. Tsutsumi, Y. Konishi, O.I. Kaplan, H. Kunitomo, Y. Iino, O.E. Blacque, M. Setou, Identification of tubulin deglutamylase among Caenorhabditis elegans and mammalian cytosolic carboxypeptidases (CCPs), J Biol Chem 285 (2010) 22936-22941.

[57] S. Kitano, Y. Kino, Y. Yamamoto, M. Takitani, J. Miyoshi, T. Ishida, Y. Saito, K. Arima, J.-I. Satoh, Bioinformatics Data Mining Approach Suggests Coexpression of AGTPBP1 with an ALS-linked Gene C9orf72, J Cent Nerv Syst Dis 7 (2015) 15-26.

[58] S.-i. Kyuhou, N. Kato, H. Gemba, Emergence of endoplasmic reticulum stress and activated microglia in Purkinje cell degeneration mice, Neurosci Lett 396 (2006) 91-96.

[59] B. Lacroix, J. van Dijk, N.D. Gold, J. Guizetti, G. Aldrian-Herrada, K. Rogowski, D.W. Gerlich, C. Janke, Tubulin polyglutamylation stimulates spastin-mediated microtubule severing, J Cell Biol 189 (2010) 945-954.

[60] J.C. Lambert, C.A. Ibrahim-Verbaas, D. Harold, A.C. Naj, R. Sims, C. Bellenguez, A.L. DeStafano, J.C. Bis, G.W. Beecham, B. Grenier-Boley, G. Russo, T.A. Thorton-Wells, N. Jones, A.V. Smith, V. Chouraki, C. Thomas, M.A. Ikram, D. Zelenika, B.N. Vardarajan, Y. Kamatani, C.F. Lin, A. Gerrish, H. Schmidt, B. Kunkle, M.L. Dunstan, A. Ruiz, M.T. Bihoreau, S.H. Choi, C. Reitz, F. Pasquier, C. Cruchaga, D. Craig, N. Amin, C. Berr, O.L. Lopez, P.L. De Jager, V. Deramecourt, J.A. Johnston, D. Evans, S. Lovestone, L. Letenneur, F.J. Moron, D.C. Rubinsztein, G. Eiriksdottir, K. Sleegers, 
A.M. Goate, N. Fievet, M.W. Huentelman, M. Gill, K. Brown, M.I. Kamboh, L. Keller, P. Barberger-Gateau, B. McGuiness, E.B. Larson, R. Green, A.J. Myers, C. Dufouil, S. Todd, D. Wallon, S. Love, E. Rogaeva, J. Gallacher, P. St George-Hyslop, J. Clarimon, A. Lleo, A. Bayer, D.W. Tsuang, L. Yu, M. Tsolaki, P. Bossu, G. Spalletta, P. Proitsi, J. Collinge, S. Sorbi, F. Sanchez-Garcia, N.C. Fox, J. Hardy, M.C. Deniz Naranjo, P. Bosco, R. Clarke, C. Brayne, D. Galimberti, M. Mancuso, F. Matthews, S. Moebus, P. Mecocci, M. Del Zompo, W. Maier, H. Hampel, A. Pilotto, M. Bullido, F. Panza, P. Caffarra, B. Nacmias, J.R. Gilbert, M. Mayhaus, L. Lannefelt, H. Hakonarson, S. Pichler, M.M. Carrasquillo, M. Ingelsson, D. Beekly, V. Alvarez, F. Zou, O. Valladares, S.G. Younkin, E. Coto, K.L. Hamilton-Nelson, W. Gu, C. Razquin, P. Pastor, I. Mateo, M.J. Owen, K.M. Faber, P.V. Jonsson, O. Combarros, M.C. O'Donovan, L.B. Cantwell, H. Soininen, D. Blacker, S. Mead, T.H. Mosley, Jr., D.A. Bennett, T.B. Harris, L. Fratiglioni, C. Holmes, R.F. de Bruijn, P. Passmore, T.J. Montine, K. Bettens, J.I. Rotter, A. Brice, K. Morgan, T.M. Foroud, W.A. Kukull, D. Hannequin, J.F. Powell, M.A. Nalls, K. Ritchie, K.L. Lunetta, J.S. Kauwe, E. Boerwinkle, M. Riemenschneider, M. Boada, M. Hiltuenen, E.R. Martin, R. Schmidt, D. Rujescu, L.S. Wang, J.F. Dartigues, R. Mayeux, C. Tzourio, A. Hofman, M.M. Nothen, C. Graff, B.M. Psaty, L. Jones, J.L. Haines, P.A. Holmans, M. Lathrop, M.A. Pericak-Vance, L.J. Launer, L.A. Farrer, C.M. van Duijn, C. Van Broeckhoven, V. Moskvina, S. Seshadri, J. Williams, G.D. Schellenberg, P. Amouyel, Meta-analysis of 74,046 individuals identifies 11 new susceptibility loci for Alzheimer's disease, Nat Genet 45 (2013) 1452-1458.

[61] S.C. Landis, R.J. Mullen, The development and degeneration of Purkinje cells in pcd mutant mice, J Comp Neurol 177 (1978) 125-143.

[62] J.C. Larcher, D. Boucher, S. Lazereg, F. Gros, P. Denoulet, Interaction of kinesin motor domains with alpha- and beta-tubulin subunits at a tau-independent binding site.

Regulation by polyglutamylation, J Biol Chem 271 (1996) 22117-22124.

[63] M.M. LaVail, J.C. Blanks, R.J. Mullen, Retinal degeneration in the pcd cerebellar mutant mouse. I. Light microscopic and autoradiographic analysis, J Comp Neurol 212 (1982) 217-230.

[64] D.V. Lessard, O.J. Zinder, T. Hotta, K.J. Verhey, R. Ohi, C.L. Berger, Polyglutamylation of tubulin's C-terminal tail controls pausing and motility of kinesin-3 family member KIF1A, J Biol Chem 294 (2019) 6353-6363.

[65] J. Li, E.Y. Snyder, F.H. Tang, R. Pasqualini, W. Arap, R.L. Sidman, Nna1 gene deficiency triggers Purkinje neuron death by tubulin hyperglutamylation and ER dysfunction, JCI Insight 5 (2020) e136078.

[66] L. Li, S. Jayabal, M. Ghorbani, L.-M. Legault, S. McGraw, A.J. Watt, X.-J. Yang, ATAT1 regulates forebrain development and stress-induced tubulin hyperacetylation, Cell Mol Life Sci 76 (2019) 3621-3640.

[67] K.Y. Lo, A. Kuzmin, S.M. Unger, J.D. Petersen, M.A. Silverman, KIF1A is the primary anterograde motor protein required for the axonal transport of dense-core vesicles in cultured hippocampal neurons, Neurosci Lett 491 (2011) 168-173.

[68] A.T. Lopes, T.J. Hausrat, F.F. Heisler, K.V. Gromova, F.L. Lombino, T. Fischer, L. Ruschkies, P. Breiden, E. Thies, I. Hermans-Borgmeyer, M. Schweizer, J.R. Schwarz, C. Lohr, M. Kneussel, Spastin depletion increases tubulin polyglutamylation and impairs kinesin-mediated neuronal transport, leading to working and associative memory deficits, PLoS Biol 18 (2020) e3000820.

[69] C. Maas, D. Belgardt, H.K. Lee, F.F. Heisler, C. Lappe-Siefke, M.M. Magiera, J. van Dijk, T.J. Hausrat, C. Janke, M. Kneussel, Synaptic activation modifies microtubules 
underlying transport of postsynaptic cargo, Proc Natl Acad Sci U S A 106 (2009) 87318736.

[70] S. Maday, A.E. Twelvetrees, A.J. Moughamian, E.L.F. Holzbaur, Axonal transport: cargo-specific mechanisms of motility and regulation, Neuron 84 (2014) 292-309.

[71] M.M. Magiera, S. Bodakuntla, J. Ziak, S. Lacomme, P. Marques Sousa, S. Leboucher, T.J. Hausrat, C. Bosc, A. Andrieux, M. Kneussel, M. Landry, A. Calas, M. Balastik, C. Janke, Excessive tubulin polyglutamylation causes neurodegeneration and perturbs neuronal transport, EMBO J 37 (2018) e100440.

[72] M.M. Magiera, P. Singh, C. Janke, SnapShot: Functions of Tubulin Posttranslational Modifications, Cell 173 (2018) 1552-1552 e1551.

[73] K.K. Mahalingan, E. Keith Keenan, M. Strickland, Y. Li, Y. Liu, H.L. Ball, M.E. Tanner, N. Tjandra, A. Roll-Mecak, Structural basis for polyglutamate chain initiation and elongation by TTLL family enzymes, Nat Struct Mol Biol 27 (2020) 802-813.

[74] D.M. Mann, Pyramidal nerve cell loss in Alzheimer's disease, Neurodegeneration 5 (1996) 423-427.

[75] S. Marcos, J. Moreau, S. Backer, D. Job, A. Andrieux, E. Bloch-Gallego, Tubulin tyrosination is required for the proper organization and pathfinding of the growth cone, PLoS ONE 4 (2009) e5405.

[76] H. Mathys, J. Davila-Velderrain, Z. Peng, F. Gao, S. Mohammadi, J.Z. Young, M. Menon, L. He, F. Abdurrob, X. Jiang, A.J. Martorell, R.M. Ransohoff, B.P. Hafler, D.A. Bennett, M. Kellis, L.-H. Tsai, Single-cell transcriptomic analysis of Alzheimer's disease, Nature 570 (2019) 332-337.

[77] F.J. McNally, A. Roll-Mecak, Microtubule-severing enzymes: From cellular functions to molecular mechanism, J Cell Biol 217 (2018) 4057-4069.

[78] C.M. Mehta, J.R. Gruen, H. Zhang, A method for integrating neuroimaging into genetic models of learning performance, Genet Epidemiol 41 (2017) 4-17.

[79] S. Millecamps, J.-P. Julien, Axonal transport deficits and neurodegenerative diseases, Nat Rev Neurosci 14 (2013) 161-176.

[80] B.Y. Monroy, D.L. Sawyer, B.E. Ackermann, M.M. Borden, T.C. Tan, K.M. OriMcKenney, Competition between microtubule-associated proteins directs motor transport, Nat Commun 9 (2018) 1487.

[81] B.Y. Monroy, T.C. Tan, J.M. Oclaman, J.S. Han, S. Simo, S. Niwa, D.W. Nowakowski, R.J. McKenney, K.M. Ori-McKenney, A Combinatorial MAP Code Dictates Polarized Microtubule Transport, Dev Cell (2020).

[82] R.J. Mullen, E.M. Eicher, R.L. Sidman, Purkinje cell degeneration, a new neurological mutation in the mouse, Proc Natl Acad Sci U S A 73 (1976) 208-212.

[83] R. Munoz-Castaneda, D. Diaz, L. Peris, A. Andrieux, C. Bosc, J.M. Munoz-Castaneda, C. Janke, J.R. Alonso, M.-J. Moutin, E. Weruaga, Cytoskeleton stability is essential for the integrity of the cerebellum and its motor- and affective-related behaviors, Sci Rep 8 (2018) 3072.

[84] K. Natarajan, S. Gadadhar, J. Souphron, M.M. Magiera, C. Janke, Molecular interactions between tubulin tails and glutamylases reveal determinants of glutamylation patterns, EMBO Rep 18 (2017) 1013-1026.

[85] S. O'Gorman, Degeneration of thalamic neurons in "Purkinje cell degeneration" mutant mice. II. Cytology of neuron loss, J Comp Neurol 234 (1985) 298-316.

[86] S. O'Gorman, R.L. Sidman, Degeneration of thalamic neurons in "Purkinje cell degeneration" mutant mice. I. Distribution of neuron loss, J Comp Neurol 234 (1985) 277-297. 
[87] A. Osseni, A. Ravel-Chapuis, J.-L. Thomas, V. Gache, L. Schaeffer, B.J. Jasmin, HDAC6 regulates microtubule stability and clustering of AChRs at neuromuscular junctions, J Cell Biol 219 (2020) e201901099.

[88] A.T. Pagnamenta, P. Heemeryck, H.C. Martin, C. Bosc, L. Peris, I. Uszynski, S. GoryFaure, S. Couly, C. Deshpande, A. Siddiqui, A.A. Elmonairy, S. Jayawant, S. Murthy, I. Walker, L. Loong, P. Bauer, F. Vossier, E. Denarier, T. Maurice, E.L. Barbier, J.-C. Deloulme, J.C. Taylor, E.M. Blair, A. Andrieux, M.-J. Moutin, Defective tubulin detyrosination causes structural brain abnormalities with cognitive deficiency in humans and mice, Hum Mol Genet 28 (2019) 3391-3405.

[89] L. Paturle-Lafanechere, B. Eddé, P. Denoulet, A. Van Dorsselaer, H. Mazarguil, J.P. Le Caer, J. Wehland, D. Job, Characterization of a major brain tubulin variant which cannot be tyrosinated, Biochemistry 30 (1991) 10523-10528.

[90] S. Perry, B. Kiragasi, D. Dickman, A. Ray, The Role of Histone Deacetylase 6 in Synaptic Plasticity and Memory, Cell Rep 18 (2017) 1337-1345.

[91] L. Qiang, W. Yu, A. Andreadis, M. Luo, P.W. Baas, Tau protects microtubules in the axon from severing by katanin, J Neurosci 26 (2006) 3120-3129.

[92] C. Regnard, E. Desbruyeres, J.C. Huet, C. Beauvallet, J.C. Pernollet, B. Eddé, Polyglutamylation of nucleosome assembly proteins, J Biol Chem 275 (2000) 1596915976.

[93] C. Regnard, D. Fesquet, C. Janke, D. Boucher, E. Desbruyeres, A. Koulakoff, C. Insina, P. Travo, B. Eddé, Characterisation of PGs1, a subunit of a protein complex copurifying with tubulin polyglutamylase, J Cell Sci 116 (2003) 4181-4190.

[94] B. Rico, H.E. Beggs, D. Schahin-Reed, N. Kimes, A. Schmidt, L.F. Reichardt, Control of axonal branching and synapse formation by focal adhesion kinase, Nat Neurosci 7 (2004) 1059-1069.

[95] M. Rodriguez de la Vega, R.G. Sevilla, A. Hermoso, J. Lorenzo, S. Tanco, A. Diez, L.D. Fricker, J.M. Bautista, F.X. Aviles, Nna1-like proteins are active metallocarboxypeptidases of a new and diverse M14 subfamily, Faseb J 21 (2007) 851865.

[96] K. Rogowski, J. van Dijk, M.M. Magiera, C. Bosc, J.-C. Deloulme, A. Bosson, L. Peris, N.D. Gold, B. Lacroix, M. Bosch Grau, N. Bec, C. Larroque, S. Desagher, M. Holzer, A. Andrieux, M.-J. Moutin, C. Janke, A family of protein-deglutamylating enzymes associated with neurodegeneration, Cell 143 (2010) 564-578.

[97] A. Roll-Mecak, The Tubulin Code in Microtubule Dynamics and Information Encoding, Dev Cell 54 (2020) 7-20.

[98] S. Roy, B. Zhang, V.M.-Y. Lee, J.Q. Trojanowski, Axonal transport defects: a common theme in neurodegenerative diseases, Acta Neuropathol 109 (2005) 5-13.

[99] M. Rüdiger, U. Plessman, K.D. Kloppel, J. Wehland, K. Weber, Class II tubulin, the major brain beta tubulin isotype is polyglutamylated on glutamic acid residue 435 , FEBS Lett 308 (1992) 101-105.

[100] S. Rumpf, N. Wolterhoff, S. Herzmann, Functions of Microtubule Disassembly during Neurite Pruning, Trends Cell Biol 29 (2019) 291-297.

[101] S. Salinas, R.E. Carazo-Salas, C. Proukakis, J.M. Cooper, A.E. Weston, G. Schiavo, T.T. Warner, Human spastin has multiple microtubule-related functions, J Neurochem 95 (2005) 1411-1420.

[102] S. Saxena, P. Caroni, Selective neuronal vulnerability in neurodegenerative diseases: from stressor thresholds to degeneration, Neuron 71 (2011) 35-48. 
[103] N.T. Seyfried, E.B. Dammer, V. Swarup, D. Nandakumar, D.M. Duong, L. Yin, Q. Deng, T. Nguyen, C.M. Hales, T. Wingo, J. Glass, M. Gearing, M. Thambisetty, J.C. Troncoso, D.H. Geschwind, J.J. Lah, A.I. Levey, A Multi-network Approach Identifies Protein-Specific Co-expression in Asymptomatic and Symptomatic Alzheimer's Disease, Cell Syst 4 (2017) 60-72 e64.

[104] V. Shashi, M.M. Magiera, D. Klein, M. Zaki, K. Schoch, S. Rudnik-Schoneborn, A. Norman, O. Lopes Abath Neto, M. Dusl, X. Yuan, L. Bartesaghi, P. De Marco, A.A. Alfares, R. Marom, S.T. Arold, F.J. Guzman-Vega, L.D. Pena, E.C. Smith, M. Steinlin, M.O. Babiker, P. Mohassel, A.R. Foley, S. Donkervoort, R. Kaur, P.S. Ghosh, V. Stanley, D. Musaev, C. Nava, C. Mignot, B. Keren, M. Scala, E. Tassano, P. Picco, P. Doneda, C. Fiorillo, M.Y. Issa, A. Alassiri, A. Alahmad, A. Gerard, P. Liu, Y. Yang, B. Ertl-Wagner, P.G. Kranz, I.M. Wentzensen, R. Stucka, N. Stong, A.S. Allen, D.B. Goldstein, B. Schoser, K.M. Rosler, M. Alfadhel, V. Capra, R. Chrast, T.M. Strom, E.J. Kamsteeg, C.G. Bonnemann, J.G. Gleeson, R. Martini, C. Janke, J. Senderek, Loss of tubulin deglutamylase CCP1 causes infantile-onset neurodegeneration, EMBO J 37 (2018) e100540.

[105] R. Sheffer, M. Gur, R. Brooks, S. Salah, M. Daana, N. Fraenkel, E. Eisenstein, M. Rabie, Y. Nevo, C. Jalas, O. Elpeleg, S. Edvardson, T. Harel, Biallelic variants in AGTPBP1, involved in tubulin deglutamylation, are associated with cerebellar degeneration and motor neuropathy, Eur J Hum Genet 27 (2019) 1419-1426.

[106] S.C. Shin, S.-K. Im, E.-H. Jang, K.S. Jin, E.-M. Hur, E.E. Kim, Structural and Molecular Basis for Katanin-Mediated Severing of Glutamylated Microtubules, Cell Rep 26 (2019) 1357-1367 e1355.

[107] V. Siahaan, J. Krattenmacher, A.A. Hyman, S. Diez, A. Hernandez-Vega, Z. Lansky, M. Braun, Kinetically distinct phases of tau on microtubules regulate kinesin motors and severing enzymes, Nat Cell Biol 21 (2019) 1086-1092.

[108] C.G. Silva, E. Peyre, M.H. Adhikari, S. Tielens, S. Tanco, P. Van Damme, L. Magno, N. Krusy, G. Agirman, M.M. Magiera, N. Kessaris, B. Malgrange, A. Andrieux, C. Janke, L. Nguyen, Cell-Intrinsic Control of Interneuron Migration Drives Cortical Morphogenesis, Cell 172 (2018) 1063-1078.

[109] M. Sirajuddin, L.M. Rice, R.D. Vale, Regulation of microtubule motors by tubulin isotypes and post-translational modifications, Nat Cell Biol 16 (2014) 335-344.

[110] J.N. Sleigh, A.M. Rossor, A.D. Fellows, A.P. Tosolini, G. Schiavo, Axonal transport and neurological disease, Nat Rev Neurol 15 (2019) 691-703.

[111] S.A. Small, S. Simoes-Spassov, R. Mayeux, G.A. Petsko, Endosomal Traffic Jams Represent a Pathogenic Hub and Therapeutic Target in Alzheimer's Disease, Trends Neurosci 40 (2017) 592-602.

[112] C. Sotelo, R.M. Alvarado-Mallart, Reconstruction of the defective cerebellar circuitry in adult Purkinje cell degeneration mutant mice by Purkinje cell replacement through transplantation of solid embryonic implants, Neuroscience 20 (1987) 1-22.

[113] X. Sun, J.H. Park, J. Gumerson, Z. Wu, A. Swaroop, H. Qian, A. Roll-Mecak, T. Li, Loss of RPGR glutamylation underlies the pathogenic mechanism of retinal dystrophy caused by TTLL5 mutations, Proc Natl Acad Sci U S A 113 (2016) E2925-2934.

[114] R. Tan, A.J. Lam, T. Tan, J. Han, D.W. Nowakowski, M. Vershinin, S. Simo, K.M. OriMcKenney, R.J. McKenney, Microtubules gate tau condensation to spatially regulate microtubule functions, Nat Cell Biol 21 (2019) 1078-1085.

[115] S. Tanco, O. Tort, H. Demol, F.X. Aviles, K. Gevaert, P. Van Damme, J. Lorenzo, Cterminomics screen for natural substrates of cytosolic carboxypeptidase 1 reveals processing of acidic protein C termini, Mol Cell Proteomics 14 (2015) 177-190. 
[116] M.A. Tischfield, G.Y. Cederquist, M.L. Gupta, Jr., E.C. Engle, Phenotypic spectrum of the tubulin-related disorders and functional implications of disease-causing mutations, Curr Opin Genet Dev 21 (2011) 286-294.

[117] O. Tort, S. Tanco, C. Rocha, I. Bieche, C. Seixas, C. Bosc, A. Andrieux, M.-J. Moutin, F. Xavier Aviles, J. Lorenzo, C. Janke, The cytosolic carboxypeptidases CCP2 and CCP3 catalyze posttranslational removal of acidic amino acids, Mol Biol Cell 25 (2014) 3017-3027.

[118] L.C. Triarhou, Rate of neuronal fallout in a transsynaptic cerebellar model, Brain Res Bull 47 (1998) 219-222.

[119] S.K. Tyagarajan, J.-M. Fritschy, Gephyrin: a master regulator of neuronal function?, Nat Rev Neurosci 15 (2014) 141-156.

[120] M.L. Valenstein, A. Roll-Mecak, Graded Control of Microtubule Severing by Tubulin Glutamylation, Cell 164 (2016) 911-921.

[121] J. Valero, M.T. Berciano, E. Weruaga, M. Lafarga, J.R. Alonso, Pre-neurodegeneration of mitral cells in the pcd mutant mouse is associated with DNA damage, transcriptional repression, and reorganization of nuclear speckles and Cajal bodies, Mol Cell Neurosci 33 (2006) 283-295.

[122] R. van den Berg, C.C. Hoogenraad, R.Q. Hintzen, Axonal transport deficits in multiple sclerosis: spiraling into the abyss, Acta Neuropathol 134 (2017) 1-14.

[123] J. van Dijk, J. Miro, J.-M. Strub, B. Lacroix, A. van Dorsselaer, B. Eddé, C. Janke, Polyglutamylation Is a Post-translational Modification with a Broad Range of Substrates, J Biol Chem 283 (2008) 3915-3922.

[124] J. van Dijk, K. Rogowski, J. Miro, B. Lacroix, B. Eddé, C. Janke, A targeted multienzyme mechanism for selective microtubule polyglutamylation, Mol Cell 26 (2007) 437-448.

[125] J.I. Velez, F. Lopera, H.R. Patel, A.S. Johar, Y. Cai, D. Rivera, C. Tobon, A. Villegas, D. Sepulveda-Falla, S.G. Lehmann, S. Easteal, C.A. Mastronardi, M. Arcos-Burgos, Mutations modifying sporadic Alzheimer's disease age of onset, Am J Med Genet B Neuropsychiatr Genet 171 (2016) 1116-1130.

[126] T. Wang, J.I. Morgan, The Purkinje cell degeneration (pcd) mouse: an unexpected molecular link between neuronal degeneration and regeneration, Brain Res 1140 (2007) 26-40.

[127] T. Wang, J. Parris, L. Li, J.I. Morgan, The carboxypeptidase-like substrate-binding site in Nnal is essential for the rescue of the Purkinje cell degeneration (pcd) phenotype, Mol Cell Neurosci 33 (2006) 200-213.

[128] A. Wolff, B. de Nechaud, D. Chillet, H. Mazarguil, E. Desbruyeres, S. Audebert, B. Eddé, F. Gros, P. Denoulet, Distribution of glutamylated alpha and beta-tubulin in mouse tissues using a specific monoclonal antibody, GT335, Eur J Cell Biol 59 (1992) 425-432.

[129] H.-Y. Wu, T. Wang, L. Li, K. Correia, J.I. Morgan, A structural and functional analysis of Nna1 in Purkinje cell degeneration (pcd) mice, FASEB J 26 (2012) 4468-4480.

[130] H. Zempel, J. Luedtke, Y. Kumar, J. Biernat, H. Dawson, E. Mandelkow, E.-M. Mandelkow, Amyloid-beta oligomers induce synaptic damage via Tau-dependent microtubule severing by TTLL6 and spastin, EMBO J 32 (2013) 2920-2937.

[131] F. Zhang, B. Su, C. Wang, S.L. Siedlak, S. Mondragon-Rodriguez, H.-G. Lee, X. Wang, G. Perry, X. Zhu, Posttranslational modifications of alpha-tubulin in alzheimer disease, Transl Neurodegener 4 (2015) 9. 